\title{
SMALL AND MEDIUM-SIZED ENTERPRISES IN DENMARK
}

\begin{abstract}
The Kingdom of Denmark is one of the most prosperous countries in the European Union. Denmark is leading the rankings on both the standard of living of the citizens, as well as the rankings of the best economies and most business-friendly countries. It is therefore a country that more attention should be devoted and we should draw experiences that can be implemented in Poland. The purpose of this article is to discuss the sector of micro, small and mediumsized enterprises in Denmark, with a particular focus on the strengths of the SME sector as well as barriers to its development.
\end{abstract}

K e y w o r d s: SME; micro; small and medium-sized enterprises; Denmark.

Klasyfikacja JEL: O52

\section{INTRODUCTION}

Small and medium-sized enterprises (SMEs) are often referred as the backbone of the European economy, acting by a potential ource of employment and economic growth. In 2010 they constituted $99.8 \%$ of all enterprises in the European Union. Considering the increasing role of this sector in achieving a high quality of life for European citizens, creating good conditions for the development of the SME sector is a key element of European economic policy.

* Adres do korespondencji: Eunika Jedynak, Uniwersytet Mikołaja Kopernika w Toruniu, Wydział Nauk Ekonomicznych i Zarządzania, Katedra Marketingu i Handlu, ul. Gagarina 13,87-100 Toruń, e-mail: eunika@doktorant.umk.pl. 
Denmark is one of the most prosperous countries of the European Union. According to the report Legatum Institute's 2014 Prosperity Index, the country was ranked fourth among the countries with the greatest prosperity (as Norway, Switzerland and New Zealand) ${ }^{1}$ and in fourth place in the ranking of Doing Business in $2015^{2}$, led by the World Bank Group ${ }^{3}$

The purpose of this article is to present the characteristics of the SME sector in Denmark. In particular, the article attempts to analyze the strengths and barriers to the development of micro, small and medium-sized enterprises in this country.

\section{DENMARK - CHARACTERISTICS OF THE COUNTRY}

Denmark is the smallest of the Nordic countries ${ }^{4}$ and the oldest European monarchy with preserved continuity hereditary monarch's power. It is headed by Queen Margrethe II and Prime Minister - Lars Løkke Rasmus$\operatorname{sen}^{5}$. Continental Denmark together with Greenland and the Faroe Islands form the Community Kingdom of Denmark, which bordered on the south of Germany and the Øresund Strait adjacent to Sweden. Most of the country (about 70\%) is located on the Jutland peninsula and the rest is located on 406 islands, of which only 76 are populated. The biggest and the most important islands of Denmark are Zealand (where Copenhagen is located), Fyn and Bornholm, and the coastline Denmark has $7314 \mathrm{~km}^{6}$.

In the area of Denmark lives 5668743 people $^{7}$ (as at 01.04.2015), mainly the city $-87.05 \%$ of its population lives in urban areas ${ }^{8}$. The popu-

Legatum Institute's 2014 Prosperity Index, p. 4.

2 Doing Business Report examines 11 areas of business in the country (including the registration of business, getting credit, paying taxes, international trade, insolvency and regulation of the labor market).

3 Bank Group, Doing Business 2015 Report, www.doingbusiness.org, [08.06.2015].

4 Nordic countries is a term with a broader meaning than the Scandinavian countries. It includes member countries of the Nordic Council: the three Scandinavian countries (Denmark, Norway and Sweden) as well as Iceland and Finland.

5 Danish Prime Minister in 2009-2011 and in 2015.

6 Economic information of the Ministry of Foreign Affairs, www.informator ekonomiczny.msz.gov.pl, [06.10.2015].

7 Danmarks Statistik, www.dst.dk, [10.06.2015].

8 Google Public Data 2014. 
lation density of the country is 132.91 people $^{9}$ per square $\mathrm{km}$. The capital of Denmark is Copenhagen (located on Zealand) with a population of 540 thousand people. Other major cities in Denmark are: Aarhus (approx. 250 thousand inhabitants), Odense (167 thousand inhabitants), Aalborg (approx. 104 thousand inhabitants), Esbjerg (72 thousand inhabitants) and Randers (60 thousand inhabitants). It is worth emphasizing that the population of the largest city in Denmark is $25.43 \%$ of the total urban population. For comparison in Poland it is $7.47 \%$.

Danes in Denmark represent more than $88 \%$ of its residents ${ }^{10}$. According to the Danish Statistical Office for the first quarter of 2015, 11.6\% of the population in Denmark are immigrants or their descendants ${ }^{11}$. Poles, according to data for the first quarter of 2015, are the second (after the immigrants from Turkey $-1.09 \%$ ) ethnic group in Denmark $-0.71 \%$. The official language in Denmark is Danish. On the dependent territories of Denmark are also used local languages: Greenlandic and Faroese. Danes have a high knowledge of English, which is taught $100 \%$ of children in schools, and they often also learn German language.

Denmark is a member of the European Union since 1st January 1973 and a member of the OECD (as a country of incorporation actively participates in the work of the OECD in monitoring the activities of many committees), NATO, the UN, the Organization for Security and Cooperation in Europe, Council of Europe, the Nordic Union and other international organizations. In 2015, as the first Nordic country, Denmark has acceded to China created by the Asian Infrastructure Investment Bank (AIIB). Denmark is a member of the Schengen zone since 25th March 2001. The currency in Denmark is the Danish Krone (DKK). Denmark maintains a stable exchange rate of the crown against the euro (EUR / DKK - 7.24'12).

Denmark's economy is highly developed. The high level of development of the country is mainly due to technological advancement and wellidentified market niches. In the last five years of advanced technology sectors based on knowledge and innovation, such as biotechnology, climate, information technology and electronics, experienced significant growth ${ }^{13}$.

9 Ibidem.

10 Global Statistics, http://joshuaproject.net, [10.06.2015].

11 Denmark Statistic, http://www.statbank.dk, [10.06.2015].

12 Biznes.pl, www.biznes.pl, state at 16.06.2015.

13 Economic information of the Ministry of Foreign Affairs, http: //www.informator ekonomiczny.msz.gov.pl, [20.06.2015]. 
In addition, the agricultural sector has a high ability to adapt to changing trading conditions (imposed by the Russian embargo on imports of agricultural and food products from the EU forced the Danish producers to seek new markets), and the Danish industry is characterized by high technical standard. A major role in Denmark plays extraction of energy resources (oil, natural gas, lignite and peat). Denmark is self-sufficient in energy. Oil and gas extraction is twice of own needs, and the surplus is exported ${ }^{14}$.

The most important sectors of the Danish economy in 2014 were: public administration, national defense, education, health and social care $(23.4 \%)$, wholesale and retail trade, transport, services related to the accommodation and food services $(19.5 \%)$ as well as the industry $(18.1 \%)^{15}$. The main export markets for the Danish economy are: Sweden and Germany (13\% of exports), United Kingdom (9.4\% of exports), United States (7.6\% of exports) and Norway (5.6\% of exports) ${ }^{16}$. The unemployment rate in Denmark is low, unemployed women represent $4.9 \%$ of women of working age, the unemployment rate for men is $4.5 \%{ }^{17}$.

\section{CHARACTERISTICS AND PROVIDED SUPPORT OF MICRO, SMALL AND MEDIUM ENTERPRISES IN DENMARKI}

Micro, small and medium-sized enterprises represent $99.4 \%$ of all businesses in Denmark, with the exception of single economic activities. Under Danish law, there is no special definition for SMEs. Data of the structure of enterprises in Denmark are presented in Table 1.1.

14 Trade and Investment Promotion Section Copenhagen, https://copenhagen. trade.gov.pl, [20.06.2015].

15 European Union, http://europa.eu, [20.06.2015].

16 Observatory of Economic Complexity, https://atlas.media.mit.edu, [20.06.2015].

17 Denmark Statistic, http://www.statbank.dk, [20.06.2015]. 
Table 1.1. The structure of enterprises in Denmark

\begin{tabular}{lcc}
\hline \multicolumn{1}{c}{$\begin{array}{c}\text { Size of enterprises } \\
\text { (number of employees) }\end{array}$} & $\begin{array}{c}\text { Number } \\
\text { of enterprises }\end{array}$ & $\%$ \\
\hline Wszystkie przedsiębiorstwa & 137686 & 100 \\
Micro, small and medium (1-249) & 136803 & 99,4 \\
Micro (1-9) & 107243 & 77,9 \\
Small (10-49) & 25480 & 18,5 \\
Medium (50-249) & 4080 & 3 \\
Big (250+) & 883 & 0,6 \\
\hline
\end{tabular}

Source: Financing SMEs and Entrepreneurs 2015: An OECD Scoreboard, OECD Report to G20 Finance Ministers and Central Bank Governors, 2015, s. 168.

In Denmark, there is the lowest share of the cost of social security for workers across Europe - at the level of $8.8 \%{ }^{18}$. According to Eurostat, Poland with the participation of social security cost for workers at the level of $17.1 \%$, is among the countries with the costs of social insurance below the EU average (21\%). This is undoubtedly a strong point of Danish enterprises - low costs for the employer allow to employ more employees.

According to 2014 data, the average time needed to set up a business in Denmark is 5.5 days $^{19}$. Time to start a business is an indicator, which tells about the degree of implementation of the friendly solutions for entrepreneurs. Denmark, compared to Poland, where according to the report, the average time to start a business is 30 days, is a country in this respect much more friendly.

The main operator representing the interests of SMEs is The Danish Federation of Small and Medium Sized Enterprises - DFSME, which works to improve the business environment for small and medium-sized enterprises in Denmark. DFSME provides consulting services in order to

18 A. Tarnawa, P. Zadura-Lichota, Raport o stanie sektora matych i średnich przedsiębiorstw w Polsce w latach 2011-2012, Polska Agencja Rozwoju Przedsiębiorczości, Warszawa 2013, p. 30.

19 The time required to start a business is the number of calendar days needed for the implementation of the procedures required to legally conduct business. If the procedure can be accelerated for an additional fee, calculated is the fastest option, regardless of the cost. 
increase the chances of SMEs to participate in the exchanges in order to establish business cooperation and develop their business in foreign markets (both neighboring Denmark and distant) ${ }^{20}$. The Association also helps affiliated companies (domestic and foreign) to implement and manage a CSR strategy (from initial analysis, by conducting workshops and training to document management and reporting of CSR activities).

The activities of SMEs in Denmark also supports Danish Commerce and Companies Agency - DCCA, which is under the Ministry of Economy and Business ${ }^{21}$. DCCA is responsible for most of the proceedings, which determine the efficiency of the Danish support system for businesses (especially SMEs). Responsibilities include the registration of companies; the administration acts which relate to matters of business; controlling and monitoring of compliance with the law without excessive disturbing controlled in their functioning; digitization (including the fact that government authorities contact enterprises only once in one case, the submission of reports is done using user-friendly and easy-to-use applications, as well as dealing with issues is at a high level of competence and fast).

Another support for enterprises is The Trade Council of Denmark, which provides assistance to small and medium-sized businesses through a network of representative offices around the world. The support consists mainly market analysis and identification of potential partners abroad. The Trade Council also helps in the preparation and the start of export, as well as programs aimed at promoting foreign sales campaigns ${ }^{22}$. It is an organizational unit of the Ministry of Foreign Affairs, which groups all the instruments responsible for promoting Danish exports and foreign investment in Denmark.

Danish Enterprise and Construction Authority operates a special portal (Startvækst), which helps entrepreneurs in business. On the website one can find tips and information both for people who are planning to start a business, and for those already operating and for entrepreneurs seeking specific help to develop your business. The agency also helps by providing tools

20 The Danish Federation of Small and Medium Sized Enterprises, http://dfsme.dk [25.06.2015].

${ }^{21}$ J. Samborski, Jak organizacje rzadowe wspieraja rodzime firmy $w$ ich działalności na rynku krajowym i zagranicznych, Europejska Unia Małych i Średnich Przedsiębiorstw oraz Klasy Średniej UNICORN, Warszawa 2011, s. 23.

22 OECD, Top Barriers and Drivers to SME Internationalisation, Report by the OECD Working Party on SMEs and Entrepreneurship, p. 19. 
that are helpful in running a business, including sample documents, budgets and business agreements ${ }^{23}$.

Analysing the financial support granted to companies, the proportion of small and medium-sized enterprises applying for loans had increased from $35 \%$ in 2007 to $44 \%$ in 2010 . The amount of loans granted to SMEs at the turn of 2007-2010 fluctuates and in 2010 reached over 48 billion Danish Crowns (about 6,6 billion EUR). The amount of loans to SMEs in Denmark at the turn of 2007-2013 are shown in Table 1.2.

Table 1.2. Loans granted to SMEs in Denmark at the turn of 2007-2010

\begin{tabular}{lccccccc}
\hline & 2007 & $\mathbf{2 0 0 8}$ & $\mathbf{2 0 0 9}$ & $\mathbf{2 0 1 0}$ & $\mathbf{2 0 1 1}$ & $\mathbf{2 0 1 2}$ & $\mathbf{2 0 1 3}$ \\
\hline $\begin{array}{l}\text { Loans } \\
\text { granted to }\end{array}$ & 40847 & 35235 & 28458 & 35062 & 34165 & 39136 & 48111 \\
$\begin{array}{l}\text { SMEs } \\
{[\text { mIn DKK] }}\end{array}$ & & & & & & & \\
\hline
\end{tabular}

* Danish Crown exchange rate to the Euro: 7,24.

Source: Financing SMEs and Entrepreneurs 2015: An OECD Scoreboard, OECD Report to G20 Finance Ministers and Central Bank Governors, 2015, s. 172.

From the $44 \%$ of SMEs that applied for funding in 2010, $23 \%$ were rejected. The chances of rejection were higher for smaller companies. Detailed data on loan applications of Danish companies in 2010 are presented in Table 1.3.

Spośród 44\% MSP, które złożyły wnioski o finansowanie w 2010 roku, $23 \% \mathrm{z}$ nich zostało odrzuconych. Szanse odrzucenia były wyższe dla mniejszych firm ${ }^{24}$. Szczegółowe dane dotyczące wniosków kredytowych duńskich firm w 2010 roku przedstawia Tabela 1.3.

23 J. Samborski, op.cit., p. 24.

24 Financing SMEs and Entrepreneurs 2015: An OECD Scoreboard, op.cit., p. 169. 
Table 1.3. The results of loan applications Danish companies in 2010

\begin{tabular}{lcccc}
\hline $\begin{array}{c}\text { Result } \\
\text { of loan appli- } \\
\text { cation }\end{array}$ & $\begin{array}{c}\mathbf{5 - 9} \\
\text { employees } \\
{[\%]}\end{array}$ & $\begin{array}{c}\mathbf{1 0 - 4 9} \\
\text { employees } \\
{[\%]}\end{array}$ & $\begin{array}{c}\mathbf{5 0 - 9 9} \\
\text { employees } \\
{[\%]}\end{array}$ & $\begin{array}{c}\mathbf{1 0 0 - 2 4 9} \\
\text { employees } \\
{[\%]}\end{array}$ \\
\hline Cetting a loan & 63 & 69 & 69 & 75 \\
$\begin{array}{l}\text { Partial getting } \\
\text { a loan }\end{array}$ & 25 & 23 & 28 & 22 \\
Rejection & 21 & 24 & 24 & 13 \\
\hline
\end{tabular}

Source: Financing SMEs and Entrepreneurs 2015: An OECD Scoreboard, OECD Report to G20 Finance Ministers and Central Bank Governors, 2015, p. 168.

The Ministry of Economic and Business of the government of Denmark analysed the ability of SMEs to obtain credit through examination of a number of financial ratios derived from their accounts.

\section{OPPORTUNITIES AND BARRIERS FOR THE DEVELOPMENT OF SMES IN DENMARK}

Small and medium-sized enterprises are an important part in many economies and play a key role in creating innovation. Therefore using opportunities and capitalizing on strengths, which the SME sector is characterized, brings benefits not only to the performance of the enterprise, but also for the overall performance of the economy of the country. This is especially important for young companies as they are in the first few years of the uprising, are most likely to struggle with serious problems, and many of them cannot cope with survival in the first year.

The main barriers which hinder or impede the development of economic activities generally include the following factors ${ }^{25}$ :

- lack of funds,

- demand for regional or local market,

- high taxes - mainly the lack of transparency of indirect taxes,

- organizational and legal conditions,

- barriers of innovation and technology,

25 Polish Entrepreneurs Portal, http://msp-24.pl, [05.08.2015]. 
- limited access to economic information,

- lack of qualified personnel on the labor market,

- lack of transparency and clarity in the calculation of income tax from business,

- inflexible labor law,

- lack of the usage of flexible forms of employment,

- complex and unclear administrative procedures,

- competition from the companies using the tax-exempt benefits,

- competition from companies operating in the "gray zone".

For many small and medium-sized enterprises in Denmark, according to a study from 2013, the challenge still remains a low level of digitization ${ }^{26}$ and usage of so-called Big Data ${ }^{27}$. Striving for a high level of digitalization leads to greater storage and usage of data, which makes easier to use the analyzes, summaries and data to build a competitive advantage on the market.

Restrictions for small and medium-sized enterprises in Denmark, when they compete with larger companies, are largely related to their smaller financial resources ${ }^{28}$. Making the investment is more difficult for them. Lack of financial resources entails the necessity to seek capital from banks or private investors, which requires the payment of interest or to sacrifice part of the profits. Another barrier to the development of SMEs in Denmark is the fact that for this group of companies market information and new technologies are less available. SMEs have much less experience in the development of new technologies, marketing of new products and entering new markets.

Another barrier to development of small and medium-sized enterprises in Denmark is the problem of access to scientific knowledge, including scientific articles, patents as well as legal information and market. It indicates a study of Access to Research and Technical Information in Denmark, carried out in $2011^{29}$. There is a need for improved access to proven (scientific)

26 Danish Business Authority, Big Data as a growth factor in Danish business potentials, barriers and business policy implications, Iris Group, https://erhvervsstyrelsen.dk, [01.09.2015].

27 Big Data is a collection of information about high-volume, high volatility or high diversity, which require new forms of treatment in order to support decision-making, discovering new phenomena and optimization of business processes.

28 Danish National Report, SMEs and competition rules, 2012, p. 9.

29 Denmark's Electronic Research Library, Access to Research and Technical Information in Denmark, Copenhagen 2011, p. 56. 
knowledge - this applies to both the availability and affordability of published information.

Small and medium-sized enterprises are undoubtedly the backbone of the economy of each country. In the past five years, European SMEs have created around $85 \%$ of new jobs and determine $2 / 3$ of the total employment in the private sector in the EU. According to the European Commission, the activities of SMEs are key to ensuring economic growth, innovation, job creation and social integration across the Union. Therefore, one should place great emphasis on the exploitation of opportunities and capitalizing on strengths, which undoubtedly small and medium-sized enterprises in Denmark have.

A chance of SMEs in Denmark are primarily actions by the EU, which support entrepreneurship through the creation of an action plan for entrepreneurship, which, among others, strengthen entrepreneurship education, and helps to create support tools for aspiring entrepreneurs. The priority of the European Commission is also to ensure that companies from the SME sector can count on a friendly business environment and the promotion of cross-border activities, both within the EU single market and beyond. The European Union also takes care of finances, because this is the most pressing problem for many small businesses. Commission acts to improve the financial environment for SMEs and provides comprehensive information on business financing ${ }^{30}$.

One of the strengths of Denmark are also powerful companies, including those in the field of biotechnology. In 2014 due to its unique solutions of fermentation, supplied for chemical companies, a Danish company Biosyntia was nominated for "most innovative European SMEs in the biotechnology sector" (Most Innovative EU Biotech SME) ${ }^{31}$. This is the proof of possession of Denmark innovative companies, the highest international standard.

\section{SUMMARY}

Danish SMEs achieve very good results in comparison with the average in the European Union. Data analysis made by the OECD shows that SMEs

30 European Commission, http://ec.europa.eu, [10.09.2015

31 Ministry of foreign affair of Denmark, Danish biotech company nominated as most innovative SME in the EU, http://www.investindk.com, [10.09.2015]. 
in Denmark follow a good trail - internationalization of its activities. There is no doubt that this fact, combined with innovation and advisory support and finance from the European Union, has the opportunity to provide them with high growth.

There are a few of the areas in Danish SMEs that still need improvement. According to published studies, still their level of digitization is inadequate - which, however, in comparison with other countries of the European Union is not a big threat. Small and medium-sized enterprises in Denmark feel the lack of access to scientific knowledge, which could be used to create innovative solutions. The SME sector feels the deficiency of financial resources that could be spent on further development - small and medium-sized enterprises, in comparison to large enterprises, have a much smaller chance of investing in new technologies, and thus - to build competitive advantage.

Forecasts for SMEs for the coming years are encouraging. Denmark is a developed country and the level of development is mainly due to technological advancements. In recent years, a significant increase recorded not only the biotech sector, but also information technology and electronics industry and the climate (high technology sectors based on knowledge and innovation). Danish companies also specialize in finding market niches, which definitely positive forecasts for their development in the coming years.

\section{BIBLIOGRAPHY}

Biznes.pl, www.biznes.pl.

Danish Business Authority, Big Data as a growth factor in Danish business potentials, barriers and business policy implications, Iris Group, https:// erhvervsstyrelsen.dk.

Danish National Report, SMEs and competition rules, 2012.

Danmarks Statistik, www.dst.dk.

Denmark Statistic, http://www.statbank.dk.

Denmark's Electronic Research Library, Access to Research and Technical Information in Denmark, Copenhagen 2011.

Eksplorator danych publicznych Google, Google Public Data 2014.

European Commission, http://ec.europa.eu. 
Financing SMEs and Entrepreneurs 2015: An OECD Scoreboard, OECD Report to G20 Finance Ministers and Central Bank Governors, 2015.

Global Statistics, http://joshuaproject.net.

Economic information of the Ministry of Foreign Affairs, www.informatorekonomiczny.msz.gov.pl.

Legatum Institute's 2014 Prosperity Index.

Ministry of foreign affair of Denmark, Danish biotech company nominated as most innovative SME in the EU, http://www.investindk.com.

Observatory of Economic Complexity, https://atlas.media.mit.edu.

OECD, Top Barriers and Drivers to SME Internationalisation, Report by the OECD Working Party on SMEs and Entrepreneurship.

Polish Entrepreneurs Portal, http://msp-24.pl.

Samborski J., Jak organizacje rządowe wspieraja rodzime firmy w ich działalności na rynku krajowym i zagranicznych, Europejska Unia Małych i Średnich Przedsiębiorstw oraz Klasy Średniej UNICORN, Warszawa 2011.

Tarnawa A., Zadura-Lichota P., Raport o stanie sektora malych $i$ średnich przedsiębiorstw w Polsce w latach 2011-2012, Polska Agencja Rozwoju Przedsiębiorczości, Warszawa 2013.

The Danish Federation of Small and Medium Sized Enterprises, http://dfsme.dk.

Trade and Investment Promotion Section Copenhagen, https://copenhagen.trade. gov.pl.

Unia Europejska, http://europa.eu.

World Bank Group, Doing Business 2015 Report, www.doingbusiness.org.

\section{SEKTOR MŚP W DANII}

Zarys treści: Królestwo Danii jest jednym z najbardziej prosperujących krajów w Unii Europejskiej. Dania przoduje w rankingach, dotyczących zarówno standardu życia obywateli tego kraju, jak również w rankingach najlepszych gospodarek czy państw najbardziej przyjaznych dla biznesu. Jest to zatem kraj, któremu warto poświęcić więcej uwagi i czerpać doświadczenia, które mogą zostać wdrożone w Polsce. Celem niniejszego artykułu jest omówienie sektora mikro, małych i średnich przedsiębiorstw działających na terenie Danii, ze szczególnym uwzględnieniem mocnych stron sektora MSP, jak i barier w jego rozwoju.

Słowa kluczowe: MŚP; mikro-; małe i średnie przedsiębiorstwa; Dania. 